UDC 329(=163.41)(560)“18“"

Саша Марковић

Универзитет уНовом Саду

Педагошки факултет Сомбор

milnik.markovic@gmail.com
Оригиналан научни рад

примљено: 12. април 2012

прихваћено: 1. октобар 2012

\title{
ПОЛИТИКАНСТВО ИЛИ ПРОЛЕГОМЕНА ДЕМОКРАТСКЕ СТРАНКЕ КОД ВОЈВОЪАНСКИХ СРБА АУСТРО-УГАРСКЕ МОНАРХИЈЕ
}

Сажетак: Политички положај Срба у Угарској, тачније у њеном јужном делу, почетком 20. века био је веома комплексан. Иако се Аустро-Угарска монархија трудила да своју друштвену ситуацију интерпретира као последицу значајног напредовања демократских тековина, реалност је имала једва додирних тачака са таквим констатацијама. Вишенационална демографска структура становништва Угарске кохерентно је условљава демократизацију друштва ради њеног опстанка. Ипак термин демократска Угарска је, без икаквих искрених намера да се оствари, а сведен на декларативно штиво и политички промискуитет, остао оксиморон чију су аутентичност осведочила многобројна истраживања. У таквој политичкој недоречености која је, како се продубљивала интересна напетост и конфликт постајао парадигма међународних односа, постепено клизила у мађарску националну олигократију, политичка и страначка артикулација и Срба био је врло неизвестан подухват. И сами политички представници српског народа у Војводини, оптерећени страначким антагонизмом и интересним политиканством, додатно су усложњавали проблем. Било која идеја или политичка акција посматрани су кроз призму сопственог успеха или неуспеха. Отуд је и етикетирање постало уобичајно, а сваки иоле либералнији покушај остао је у сенци оптужби за опортунизам. Деградација и међусобно проказивање додатно су ослабили идентитет политичке елите Срба. Последица тога било је и беспомоћно посматрање укидања црквено-школске аутономије Срба у монархији. Једино поље успешног рада било је институционално али и појединачно афирмисање културно-образовне делатности код Срба, као најзначајнијег сегмента формирања одговорне нације. демократија.

Кључне речи: Срби, политика, национални идентитет, странка, Угарска,

\footnotetext{
* Овај рад настао је као резултат истраживања у оквиру пројекта Друштвени односи Срба и Хрвата, национални идентитет и мањинска права са аспекта европских интеграција.
} 


\section{Ранија истраживања}

О покушају стварања Српске Демократске странке у Војводини није се довољно писало, а то је последица обима истраживања тематске одреднице. Разлог томе треба тражити и у маргиналнијем значају за политички живот Срба, иницијативе за оснивањем ове странке с обзиром на постојеће политичке странке, али треба нагласити да постоји и други разлог који проистиче из недовољног разумевања идејних начела на којима су се ставови представника демократске идеје заснивали. С обзиром на то да се радило о образованим људима њихова упућеност у модерне демократске, либералне и националне идеје била је актуелна и европски орјентисана. Из тог разлога један део историографије која се и бавила политичким животом Срба у Војводини у време Аустро-Угарске монархије непосредно пред Први светски рат, паушално је користио мериторне идеолошке оцене за дискредитацију намере до домета појединачне уобразиље. ${ }^{1}$ Инструметализовани приступ ипак није обесмислио сваку написану реч. Истраживања заснована на историјским изворима сведоче о њиховој ванвременској валидности и незаобилазно су полазиште за даља проучавања. Њихова детектована задршка, у вези са нашом темом односи се на тек присутну аберацију приликом проучавања ширих истраживачких целина са једне стране, и недовољно проучавање савременог националног и европскох идејног исходишта демократске идеје са друге стране. ${ }^{2}$ Отуд је у истраживању доминирало представљање политичке и страначке манифестације уз констатацију идеолошке комплексности, без дубље проницљивости. "Тешко је рећи шта преовладава у неким чланцима листа демората." $^{3}$ Овим доступна истраживања нису дезавуисана, шта више она су незаобилазни постамент даљег рада јер нам омогућавају лакше детектовање циља истраживања.

\footnotetext{
1 “При објашњавању процес кои су довели до слома Хабзбуршке Империје треба, дакле, правити разлику између политике буржоазије потлачених народа и револуционарне борбе трудбеничких класа, између политичких циљева буржоазије и (недовољно јасно осмишљених) револуционарних тежњи трудбеничких маса за социјалним и националним ослобођењем и разарањем старог буржоасковелепоседничког државног апарата насиља многонационалне Монархије Хабзбурговаца.“; Никола Петровић, Национални и сочијални покрети и юихови носиощи 1914-1918. у Војводини, Зборник радова Стварање југословенске државе 1918, Институт за савремену историју, Народна књига, Београд 1983, 234.

${ }^{2}$ Најупућеније се идејом Српске демократске странке у Војводини у време Аустро-Угарске монархије бавио Арпад Лебл приликом проучавања страначког живота и појединих истакнутих личности из Војводине на прелазу 19. у 20. век, а потом и Лазар Ракић у домашајном оквиру истраживања о Радикалној странци. Арпад Лебл, Грађанске партије у Војводини 1887-1918, Филозофски факултет, Нови Сад, Институт за историју, Нови Сад 1979; Арпад Лебл, Политички лик Васе Стајића, изабрани политички и идеолошки списи, Прогрес, Нови Сад 1963; Лазар Ракић, Радикална странка у Војводини, Институт за изучавање историје Војводине, Нови Сад 1975; Лазар Ракић, Грађанске политичке странке у Војводини до Првог светског рата, Годишњак друштва историчара САП Војводине, 1976, 97-105 и др. ${ }^{3}$ Арпад Лебл, Грађанске партије у Војводини 1887-1918, Филозофски факултет, Нови Сад, Институт за историју, Нови Сад 1979, 116.
} 
Скица друштвене ситуације у Аустро-Угарској

Почетак 20. века, за Србе у Јужној Угарској, обележен је даљом политичком дисперзијом биполарног антагонистичког страначког живота. Вишенационална демографска структура становништва Угарске кохерентно је условљава демократизацију друштва ради њеног опстанка. Становништво Угарске било је готово подељено по односу броја мађарског и немађарског живља. У другој половини 19. века и почетком 20. века постојала је тенденција пораста броја Мађара, а смањења броја становника других народности. За један од разлога ове тенденције савременици немађари су сматрали асимилацију. „Државни пописи становиштва (редовно спровођени од 1869. сваке десете године) тек су од 1880. бележили националну припадност. На основу упоређења пописа из 1851. (који је такође бележио националну припадност), може се закључити да је број Мађара у Мађарској (без Хрватске) у односу на укупно становништво од 11.609 .000 био око $40 \%$, док је њихов проценат по попису из 1880 . износио 46,7\% (од свеукупног становништва од 13.749.603), док је њихов проценат 1900. по попису износио 51,4\% (од 16.838.255), а 1910. по последњем попису пред Први светски рат удео Мађара у целокупном становништву Мађарске, износио је 54,5\% (18.264.533)... У посматраном раздобљу (1880-1910) број Мађара је порастао за око 34\%, док је припадника народности у просеку порастао за 17\%...“ Број Срба, у односу на целокупно становништво износио је $3,1 \%{ }^{4}$

Вишенационална структура Аустро-Угарске монархије била је специфичан простор на којем се хегемони национализам Аустријанаца и Мађара најчешће испољавао кроз искључиви политички и страначки израз и тиме довео унутрашњеполитичку ситуацију у земљи до националних удаљавања и антагонизама. Таква ситуација је кроз законску регулативу легализована и њен ослонац био је режим и њен репресивни апарат. Истовремено, нарочито се Угарска трудила да стварно стање прикрије, и Европи прикаже своју одлучност на путу ка демократизацији друштва, једном својеврсном медијском популаризацијом вредности за које се залагала оличеним у мађарском космополитском национализму.

Политички галиматијас био је препознат у својеврсном амалгаму реалности и фикције. Страначки програми и њихове прагматичне активности доприносили су омаловажавању било каквог зрелијег приступа, штавише поспешивали су илузорност политичке идеје. Угарска, као уосталом и читава монархија се, пред Први светски рат, заглибила у муљ сопственог национализма који је од бројне популације немађарских народа у Угарској створио или политичке послушнике или политичке отпаднике. Уважавајући ове опскурне специфичности и Срби су трагали за својим политичким изразом. Он је био условљен поменутом општом ситуацијом у Монархији, али и значајним бројем специфичних чинилаца. Демографско

\footnotetext{
${ }^{4}$ Magzarország története, VI, 1148-1152; Magzarország története, VII, 414; Magzarország története, VII/1, 414. Цитирано према: Тибор, Пал, Мађарско политичко јавно мњење и српско питање на Балкану 1903-1914 , докторска дисертација, Филозофски факултет, Нови Сад, 2010, 79 и 80.
} 
присуство Срба у Угаској и страначко наслеђе исходишно везано за стваралаштво Светозара Милетића, а потом расплинуто у биполарни страначки антагонизам Радикала и Либерала били су конституитивни елементи политичке експресије. „У последњој деценији 19. века и првих година 20. века на поприштима политичке борбе отворено су се сучељавале две супарничке српске странке: Радикална и Либерална (потоња и даље као Српска народна слободоумна странка), док Народна странка нотабилитета из 1884. године није успела да се одржи на политичкој позорници.“5 Тада се покушај политичког израза обогаћује и јачањем грађанске интелигенције, институционалним ширењем школства и образовања, упознавањем са савременим европским идејама и трагањем за препознатим али и новим одредницама националног идентитета. Ови нови садржаји указују на две битне ствари. Најпре да је политичка активност процес који еволуира у скалду са контекстом времена у којем настаје и да је тенденција страначког живота усмерена ка све ширем обједињењу народа око националне експресије. ${ }^{6}$

Релативна малобројност Срба у Угарској, свега око 3\% по попису из 1910. године, наводила је њихову политичку елиту да се окрену сарадњи са другим немађарским народима, с обзиром на то да су они у целини чинили готово половичан број становника, или да прихвате политички комформизам и сарађују са мађарским странкама. У таквој структури становништва, крхка мађаркса већина ослањала се на асимилаторску националну политику. Проблем мађаризације становништва постао је основни изазов политичкој елити немађара. „Мађарски државници, на челу са Апоњијем, веровали су да ће се на основу овога школског закона све националне мањине Угарске у времену од 40 година потпуно помађарити.“7 Ова асимилација спроводила се кроз намеру стварања јединственог политичког народа као својеврсне симбиозе разних етногрупа Угарске у јединствену мађарску политичку нацију. Окосница ове државне политике били су ригидни школски закони, каква јев био тзв. Апоњијев закон из 1907. године. „У Француској 'nation' значи политички народ. Но данашња државна наука не може да призна политички народ, јер у истину таковога не може бити...Тај Апоњијев предлог учинио је најгори утисак на све немађарске народе у Уграској.“9 Такав империјализам државне политике Угарске прикривао се иза идеје интегративног космополитизма коју је наводно нудила наднационална Монархија. Иако превентивно проказана, ова идеја, с обзиром на то да је носила социјалне привилегије и статус, била је озбиљна претња. Иза тог мондијалистичког декора крио се озбиљан проблем проистекао из сумњичавости, огорчења и одклона према

\footnotetext{
${ }^{5}$ Историја српског народа, књига VI-1, Од Берлинског конгреса до уједињења, 1878-1918 (1994), Српска књижевна задруга, Београд, 539.

6 "У науци нису разрађени елементи преко којих један елитини тип национализма прелази у масовни тип."; Милорад Екмеџић, Стварање Југославије, 1790 - 1918, књига 2, Просвета, Београд 1989, 476.

${ }^{7}$ Димитрије Кириловић, Помађаривање у бивмој Угарској, Нови Сад 1935, 58.

${ }^{8}$ Ближе види: Дејан Микавица, Владан Гавриловић, Горан Васин, Законски чланак XXVII, Знаменита документа за историју српског народа 1538 - 1918, Нови Сад 2007.

${ }^{9}$ Михајло Полит-Дечанчић, Беседе, III део, прва књига, Нови Сад, чланак Говор о апропријаџији и Говор о Апоњијевом школском закону, 1910, 131 и 142.
} 
националним и традиционалим вредностима. На то су упозоравали многи истакнути српски ствараоци тог времена потпу Вељка Петровића. „...Зађите само у Сомбор, Нови Сад, Суботицу, Темишвар и друге вароши угарске, па запитајте гдје им се деца школују, загледајте у кућу колико има српских књига и листова, прислушајте како се у њиховим кућама говори.“10 Оданост српској националној идеји представљан је као покушај деструкције грађанске државе, а прихватање припадности једниственој мађарској политичкој нацији, препознати терми за овај концепт је „државни национализам“11, тумачио се, од стране власти, као цивилизацијски гест и стимуланс квалитета како индивидуалног живота тако и друштва у целини.

Странчарење које је дезавуисало идеју јединственог наступа у циљу очувања националног интереса наметало је водећим националним образовним и културним институцијама и појединцима да се покрену у осмишљавању националног идентитета на културним и либерално-демократским основама а како би била превладала неразумна и контрапродуктивна страначка и политикантска подвојеност. Покренут је широк фронт активности чија је намера била обрачун са увреженом стереотипијом о српском национализму као реметилачком фактору, и амбивалентности друштва у целини. Носиоци тог покрета били су културни и јавни радници, односно грађанска интелигенција која се неколико генерација уназад стварала на материјалном статусу и образовним достигнућима. Карактер ове „нове генерације“ био је, у више наврата, током протеклих деценија истраживања подвргнут критици и сумњи испољавања искрених намера.

С обзиром на то да је образовање било њихова препознатљивост, политички ставови који су из такве основе проистицали били су инсистирање на одговорности за могуће поступке и еволутивност у комплексном процесу промена. Револуционарна популарност, утемељена на популизму, коју су собом доносила каснија времена, једноставно није узимала у обзир овакав метод политичке борбе уз (не)свесно дезавуисање. „Став југословенских народа према Хабзбуршкој монархији изражава се највише кроз револуционарне покрете који се јављају у југословенским земљама после 1903. Ови покрети имају свој социјалнни и национални карактер.“" ${ }^{12}$ Таквом ставу доприносила је и идеолошка предрасуда али и препозната политичка снисходљивост у грађанству као један од образаца креирања успеха и личне каријере. „Грађански политичари. - Ти су, као протагонисти националног покрета у југословенским земљама, често одступали и од основних својих програмских поставки, и то колико ради става централистичке државне власти, толико и ради својих интереса.“13

\footnotetext{
${ }^{10}$ Вељко Петровић, чланци Српска интелигенција у Угарској и Искрена реч из омладине објављени у Србобрану 1904, цитирано из Вељко Петровић, Времена и догађаји, Матица српска, Нови Сад 1954, 519 и 521.

${ }^{11}$ Ситон-Ватсон, Хjy (Hugh Seton-Watson), Нације и државе, Глобус, Загреб 1977, 153.

12 Васа Чубриловић, Историја политичке мисли у Србији 19. века, Просвета, Београд 1958, 422.

${ }_{13}$ Фердо Чулиновић, Државноправна хисторија југословенских земаља 19. и 20. вијека, књига 1, Школска књига, Загреб 1956, 13.
} 
Под утицајем друштвених идеја о нацији и националном идентитету које су стизале из Европе, један број Срба Угарске из урбаних средина покушао је да осмисли нове садржаје своје националне борбе. Пресудна улога интелектуалаца у националном одређењу била је парадигма која је постојала и у многим другим земљама почев од Француске буржоаске револуције. „Аквитну улогу у формирању нација одувек су играли политичари и национални интелектуаци који су стварали патос националне идеологије.“14 Последица промишљања била је генеза става о томе да је оптималан начин парирања идеји мађарске политичке нације заправо модернизована идеја српског национализма. О њој се мало говорило и писало, јер се тумачило да такав карактер српског национализма није ни постојао.

Идеја нације, у том периоду, била је прихваћена у дискурсу тумачења француске и немачке школе национализма. Француска школа, чији је најзначајнји представник био Ернест Ренан, свој став о национализму темељила је на ирационалној актуелизацији прошлости. „Нација је душа, духовни принцип...нација предпоставља прошлост, али се оваплођује у садашњости опипљивом чињеницом пристанком који јасно испољава жељу да се настави заједнички живот.“15 Везивно ткиво такве нације јесу преци и поднете жртве за њено конституисање. „Заједничка слава у прошлости, заједничка воља у садашњости... то су битни услови да буде једна нација.... Нација је дакле велика солидарност коју сачињава осећај жртава које су принесене и за које још постоји готовост да се принесу“16

Овај концепт, без обзира на почетне различите концептуалне приступе, није био у колизији са идејом нације коју формулишу најпре Немци. Најзначајнији везивни елеменат нације, у овом контексту, био је језик. Ово позивање на језичку повезаност било је условљено неприхватљивом геополитичком ситуацијом пре свега централне и источне Европе у 19. веку, расцепкане бројним државицама унутар једног народа. Та неприхватљивост проистицала је из националноромантичарског покрета који је обједињавао етатистичку расцепканост, најпре немачког народа. Отуд и романтичарска идеја ${ }^{17}$ о јединству нације на основу језичког заједништва проистиче из учења Јохана Готфрида Хердера, немачког филозофа, о изградњи различитих нација на темељу пре свега језичке блискости. „Национални језик у свакој нацији.“ 18 Језичка повезаност, етничка блискост и усвојене културне вредности били су основа за овај тип национализма. И једна и друга концепција прозване као „француски“ или „немачки“ приступ нису биле у колизији. ${ }^{19}$ Идеолози обједињујућег типа национализма инспирисани су подједнако „стеченим историјским правима,“ заједничким језиком, међусобном геополитичком упућеношћу, релгијском бискошћу те митовима о етничкој сродности и заједничкој

\footnotetext{
${ }^{14}$ Љубомир Тадић, Наука о политици, Рад, Београд 1988, 203.

${ }^{15}$ Ернест Ренан, Шта је народ ?, 1883, 58.

${ }^{16}$ Ернест Ренан, Шта је нација?, Београд 1907, 33 и 34.

${ }^{17}$ Ближе види и Helmuth Plessner, Die verspätete Nation, Frankfurt/Main 1974.

${ }^{18}$ Јохан Готфрид Хердер, Расправа о пореклу језика, Сремски Карловци 1989, 90 и 92.

${ }^{19}$ Ближе види: Милан Суботић, На други поглед, Прилог студијама национализма, Београд 2007.
} 
прошлости. Овај својеврсни синкретизам је био основ организовања друштва и темељио се на ирационалном приступу одређењу нације који је опет имао снажно утемељење у митско-поетској верзији историје.

Италијани су с тим у вези, показали највиши ниво прагматичког амалгамирања у време националне борбе за уједињењем. ${ }^{20}$ Они су покушали да свој идентитет остваре између теоретских поставки легитимног патриотизма и националног фанатизма профилишући широку националну солидарност као израз прихватљивог консензуса за сваког појединца. Често су ови полови "националног клатна" били супротстављене вредности у тумачењу а њихов латентни додир претио је доведе до драматичних суочељавања. ${ }^{21}$ „Патриотизам, по нашем мишљењу, несумњиво припада позитивној сфери, сфери љубави...Насупрот томе ... национална свест је у теорији уверење, in actu највећим делом пркос. Она готово у потпуности живи у сфери надметања и супротстављања, дакле, на страни раздора. Узајамни односи нација могу бити племенито надметање...али су ипак остали испуњени гордошћу, похлепом, мржњом и завишћу.“22

На овај начин је денунцирана примена клишеа у приступу националном одређењу, а усвојена је концепција да је појам нације флуидан и незавршен и да настаје као резултат процеса историјског развоја. Растегљивост приступа дефиницији нације, комбинаторика, усаглашавања и аутохтоне допуне остварили су могућност свакојаке примене која је искључиво завислила од одговорности и кредибилитета тумача. С тим у вези није далеко ни одређење да је појам нације „замамно двосмислен.“ ${ }^{23}$ Нарочито у прерцепцији малих народа појам је сегрегативно прихватан и чинио је изведену и прилагодљиву синтезу. Управо та слобода тумачења омогућила перманентну актуелност термина и његову обновљиву модернизацију те прилагодљивост констелацији у датом историјском тренутку. „Парадигма национализма која је до данас најшире прихваћена јесте парадигма класичног модернизма. То је концепција по којој су нације и национализам интринсично повезани са природом модерног света и револуцијом модерности.“24

Значај језичке и етничке блискости као и осврта на „светлу“ заједничку прошлост били су препознати и код Срба у Војводини. „Реч је нераздвојна од своје појмовне садржине, па према својим асоцијативно мисаоним и националнотрадиционалним везама, она је нераздвојна и од извесних моралних рефлекса.“ 25 Поједини наши интелектуалци трагали су за аутохтоним изразом, уважавајући

\footnotetext{
${ }^{20} \mathrm{C}$ тим у вези најпознатије и најутицајније дело је програмско дело покрета "Млада Италија" које је написао Ђузепе Манцини 1851. године : La nationalita come fronte del diritto della gente (Националност као извор међународног права).

${ }^{21}$ Ближе види: Саша Марковић, Снежана Бесермењи, 'Културни национализам' у политичкој мисли код Срба почетком 20. века, Српска политичка мисао, број 4, Београд 2011, 377 - 394.

${ }^{22}$ Јохан Хајзинха, Национализам и патриотизам у Европи на крају ХІХ века, Прометеј, Нови Сад 1996, 88.

${ }^{23}$ C.J. H. Hayes, Essays on Nationalism, New York 1966, 6.

${ }^{24}$ Smith Anthony, Nationalism and Modernism: A critical survey of recent theories of nations and nationalism, London and New York, 1998, str. 3, цитирано према: Милан Суботић, На други поглед, Прилог студијама наиионализма, Београд 2007, 113.

${ }^{25}$ Вељко Петровић, Социјална улога књижевника, Рукописно одељење Матице српске (РОМС), М 17940.
} 
постојеће европске традиције. Несумњива обавештеност српске интелектуалне елите није била довољан аргумента како би се либералне вредности и образац нације прихватиле као незамењива вредност националног идентитета а још комплекснија ситуација била је у вези са политичким артикулисањем поменутих принципа. $^{26}$

Модерни тумачи и истраживачи нације, са запада, на прелазу 19. у 20. век креирају проширење етно-роматничарског садржаја национализма са културним вредностима које су утемељене на постигнутом али и на технолошком напретку и образовном усавршавању. „Нација је жеља да се сачува или повећа национални или културни идентитет народа када је тај идентитет угрожен, или жеља да се он трансформише или чак створи тамо где се осећа да је неадекватан или да недостаје.“27 Овакав концепт требао је да превлада бруталност судара постојећег тумачења етничког и политичког национализма и да из скучености прихваћених концепција пронаће парадигму интернационалног приступа. Успех одређености сопственог требао је да се мери патриотским осећањем и моралношћу који су откривали аутохтоне вредности и уврштавали их у интернационални цивилизацијски постамент. На овај начин уобразиља самодовољности испољена кроз политикоманију ирационалних представа о собству, по мишљењу ових истраживача, губила је свој raison d'etre. Концепт је понудио јединство у узвишености културних вредности водећим државама Западне Европе, и хируршки одстранио национална осећања народа који "пристижу". За њихов идентитет није било „културног спаса.“ Остали су заточени у мегаломанским пројектима сопствених националних циљева. Последица тога била је типска подела националнизама.

Отуд је проистекао тип тзв. „западног национализма“ - широкогрудог, неконфлитног и толерантног насупрот „источном типу национализма“ који је етноискључив и шовинистички структуиран јер је „имитативно реактиван.“28 Подела на овај начин устројена понудила је нову опскурну наду. Она се огледала у тумачењу национализма као афирмацији либералних идеја индивидуалне слободе и демократије, без икакве или минималне политичке интонације. Проистекло уверење из ове врсте тумачења садржавало је идеју прогресивности национализма, растерећене напетости појединца и друштва и есхатолошке наде да такав национализам може да уједини свет. ${ }^{29}$ Основни проблем ове наде био је у избору оних који су могли на њу да рачунају. У теоријским размишљањима, а ослањајући

\footnotetext{
${ }^{26}$ Ближе о томе и: Ернест Гелнер, Нације и национализам, Нови Сад 1997; Ernest Gellner, Nationalism, London 1997; Марија Тодорова, Имагинарни Балкан, Београд 2006.

${ }^{27}$ John Plamenatz, Two types of Nationalism, in Nationalism. The Nature and Evolutio of an Idea, E. Kamenka, London 1973, pp. 24-36.

${ }^{28}$ Милан Суботић, н.д, 109.

29 "...Да национализам може бити благотворна или прогресивна снага у историји само ако је етички, културни или не-политички национализам; да је културни или етички национализам најбољи начин да се минимизују тензије између појединца и заједнице; месијанску наду да такав нациоанлизам мође унапред ити светско јединство, а не довести до даљих подела."; Hans Kohn, Uber die Bedeutung des Nationalismus im Judentum und in der Gegenwart, Wien, 1922; Цитирано према, Милан Суботић,..., 94.
} 
ce на концепт достигнутог индустријског развитка, перцепција културног национализма $^{30}$ била је окренута према развијеним земљама Западне Европе.

Аналогија културни националиста је својствен једино развијеним државама Европе и западног света ${ }^{31}$ била је ослоњена на дискриминаторску предпоставку о недовољној развијености и патријахалности народа истока међу којима су били и народи са Балкана. Њихова спасоносна опција, по овом тврђењу, било је признање „заосталости““32 и уобличавање широког друштвеносг консензуса о начину њеног превладања, уз угледање на постојеће више „културне националнизме.“з3 Последица прихватања оваквог карактера националног израза била је амбивалентност чије је превладавање супротности било тешко достижно.

\section{Културно-просветни рад, испред и иза странке}

Један значајан део српске интелигенције у Угарској уочи Првог светског рата, упркос теоретским парадигмама које су њихову идеју нације и политичког иступа изопштавале из културног национализма и сврставале их у недемократска друштва митоманског романтизма, својим активностима чинили су много да појам демократски национализам не буде оксиморон, односно неостварив за српски народ. Предуслов осавремењивању националне идеје и политичких ставова било је омасовљење учествовања интелигенције у пројекту народног покрета. Српска грађанска мисао, која се увелико стварала у Новом Саду, Сомбору, Суботицу, Панчеву, Кикинди, посветила се свом новоформулисаном задатку. „Широм по целоме свету, сви се образовани народи групишу око своје интелигенције, само смо ми Срби доста лакомислени, да и оно мало образованих људи, што их још имамо, силом отуђујемо од себе .... Имамо да се одлучимо за једно од овога двога: Или ћемо се окупити око наше интелигенције, те приволети наше спремне и образоване људе, да они стану на чело у борби за народни нам опстанак...или ћемо и даље апатично трпети, да нам олош прекрли сво поље јавног живота...и онда...дани овостраног Српства биће избројани.““34

Интелигенција која се покренула трудила се да прихвати нове либералне идеје и да демократске принципе уноси у српско друштво. По њиховим речима тада је "национализам постао мач, а демократија штит српског народа." Предпоставке за успех овог широког демократског приступа националном идентитету морале су да се ослоне и на сарадњу са другим немађарским народима Угарске чија је

\footnotetext{
${ }^{30}$ Ближе види: Е. Гелнер, н. д.

31 “'Од тада се нација и држава почињу идентификовати у Западној Европи,као што се и цивилизација идентификује са националном цивилизацијом."; Hans Kohn, Nationalism: Its Meaning and History, Princeton, Van Nostrand 1955, 15.

32 John Plamenatz, н.д, pр. 30.

33 "Национализам је дошао код Словена од Њемаца...Ми морамо национализам сагледати као дио социјалне и моралне револуције чији је производ тежња ка демократији и слободи личности"; Џон Пламенац , Два типа национализма, Изабрани списи, Фондација John Plamenatz, Бар 2001, 42 и 47.

${ }^{34}$ Овако је писао један од припадника овог новог правца у политичкој мисли Срба у Угарској сомборац Јован Јоца Лалошевић. Лалошевић, Време је да се организујемо, Слога, бр. 24, 11 (24) јун 1906.
} 
национална идеја такође била спутана. О међусобној сарадњи немађара Угарске на очувању националног идентитета и његовој политичкој промоцији договорено је на великом конгресу немађарских народности Угарске одржаном 1895. године у Будимпешти. Овај Конгрес имао је великог одјека и увелико је условљавао политички прагматизам немађара, тиме и Срба. Многи водећи српски политички представници залагали су се за његово остварење. Међу њима је био и Михајло Полит Десанчић. ${ }^{35}$ „Демократија без народносне основе, без признања начела народносног програма од године 1895. сасвим је несрпска политика.“36

Најочитији покрет повезивања интелигенције са народом, спроводила је Матица српска превасходно у два одлучна наврата. ${ }^{37}$ Најпре током покушаја уздизања Матице српске из летаргије равнодушности у периоду 1900 - 1903. године када група интелектуалаца окупљена око Тихомира Остојића покреће реформаторски часопис Покрет. Идеја тзв. „Покреташа“ била је заснована на потреби образовања становништва. ${ }^{38}$ „Свесна интелигенција сваког европског народа ради на том, да књигом унесе своје идеје у народ, да га њиме пробуди, освести и упути напретку. Српска би интелигенција више него икоја имала разлог да се о том послу бави.“39 Овај реформски покушај био је кратког даха, али је истрајност и упорност, пре свих Остојића, остварена на скуптини 1. новембра 1911. године када је овај концепт победио и Остојић постављен за секретара Матице српске. Ипак политичке околности проистекле из мађарске државничке искључивости значајно су умањиле размах амбиција, али нису угасиле талас намера о очувању идентитета. „Јер сваки просвећени народ брижљиво чува своје старине,

\footnotetext{
${ }^{35}$ Ближе о Михајлу Полит Десанчићу погледај: Дејан Микавица, Михајло Полит.Десанчић, Филозофски факултет, Нови Сад 2007.

36 "Но народности кад су увиделе да им више није места у уграском сабору, дошле су на једну мисао, према којој би могуће било да у великом скупу изразе своје жеље и своје тегобе и да кажу све оно што би захтевали, с једном речи, да изиђу с једним програмом на среду. Та је била мисао: народносног конгреса, који је месеца августа 1895. одржан у Будимпешти и који је сјајно био испао."; Михајло Полит-Десанчић, Како сам свој век провео, Успомене, Нови Сад 2006, 193. "То је био величанствени народносни конгрес, држан у Будимпешти дана 10 августа 1895. Ту је утврђен народносни програм савеза Срба, Словака и Румуна. Мени је у део пала задаћа, да и стилизујем тај програм, који је после са неким малим изменама и допунама од читавог конгреса одушевљено примљен."; Михајло Полит-Дечанчић, Беседе, III део, прва књига, Нови Сад 1910, Наш положај, 271.

${ }^{37}$ Ближе види: Живан Милисавац , Историја Матице српске 1880-1918, књига III, Матица српска, Нови Сад 2000; Матица српска 1826-1926, Типографија, Загреб 1926.

38 "Књиге за народ да посредују између науке и књижевности и најширих слојева народних сељака, омладине, радика, занатлија, женског света."; Живан Милисавац, Историја Матице српске, 1826 - 1924, Нови Сад 1965, 126.

39 Конференција у Матици српској о 'књигама за народ', Тихомир Остојић, Извештај референта Редакиијског одбора, Нови Сад 1902, 6 и 7. О идеји о посвећености народу, Остојић је писао и деценију касније, изнова илуструјући своју доследност у стваралаштву. „У делима која ће да шире у нашем народу морал, износиће се начела поштења, честитости и свију других моралних врлина. Делима те врсте иде се на то да се поучава наш народ, како да чува и негује лепе своје обичаје из старина и како да се клони злих убитачних навика, било да имају свога корена у самом народу, било пак да су се одомаћиле са стране.“; Тихоми Остојић, Програм књига за народ, Летопис Матице српске, књига 294, свеска 4, Нови Сад 1913,128 и 129.
} 
остатке некадашњег својег живота, као плодове некадашње културе, као сведоке соје давнашње свести и пробућености, као миле успомене на своје прадедове.“40

„У овом контексту искреног, на моменте чак и наивног веровања у могућност акције просвећења, места за родољубље било је у несвакидашњем литерарном и идеалистичком облику који је већина тешко могла да протумачи у смислу одређења какво је замислио писац.“41 „Треба бити наиме, свестан разлике између родољубља као елементарног инстинкта, који је само један облик инстикта самоодржања, те између родољубља као вишег осећања одређеног искуством и идејом о народу...Нација се воли не као јемстсо за самоодржање, него као идеја.““2

Придавање значаја улози народа није била нова појава, али је истицање потребе за образовањем народа, доскорашњи романтичаркси популистички покрет који се позивао на народ, а заправо се наметао народу, у овој новој концепцији доживео је коперникански заокрет. Просвећени народ ${ }^{43}$ је, по њој, основни елемент будућег идентитета, а не средство за сврсисходни успех. ${ }^{44}$ Преокрет је морао да наступи у дотадашњем тумачењу националног осећања за које се писало да је „моментално и праскаво“ и да прелази из „ентузијазма у страшну апатију“ и да је слично „душевном стању једног алкохоличара.“45 Алтернатива таквом етнотериторијалном национализму требао је да буде културни национализам о којем је Исидора Секулић у еуфорији победе током балканских ратова писала: „Тај национализам треба да је и по суштини и по облику чиста, висока култура. Култура у најбољем смислу речи. Морал, хуманизам, етика, честитост. Ваљаност и честитост и првокласност не само српска, него човечанска.““6

Сви ови искази, формулисани у блиском временском оквиру, били су позив на опрез услед продора некритичког митског израза у политику и страначку делатност. Фикција сопственог арогантног става могла је да постане бумеранг излишне ступидности. „А баш је било све у нама и око нас пуно крцато Српства и братства! Али Српство више свега. Један се мој вршњак - чини ми се 'Душица' - у заносу тадашње србоманије или автоидолатрије обесмртио се чак и узвиком: Србин

\footnotetext{
${ }^{40}$ Писмо Тихомира Остојића, секретара Матице српске и Гедеона Дунђерског, председника Матице српске Славној српској православној ирквеној опћини Меленщи од 11 / 22. Октобра 1912. године; Матица српска ДК 844, Ин. Бр. 6932.

${ }^{41}$ Саша Марковић, Сомборски лист Нови Србин у трагању за културним обрасцем у националној идеји, Зборник радова Античка култура, европско и српско наслеђе, Друштво за Античке студије Србије, Институт за теолошка истраживања, Београд 2010, стр. 299.

${ }^{42}$ Васа Стајић, Песништво и родољубље, Летопис Матице српске, св. 288 1912, 4.

43 "Будимо прави просветитељи и демократе т. ј. правим од народа аристократе срца и душе, наиме не сматрајмо да је демократизам у томе ако ласкамо најгорим инстиктима још сирове народне душе", Просвећивати народ, Слога, бр. 19, 12 (25) мај 1913.

44 Савремена истраживања национализма "откривају" свакодневну употребу реторичких, емотивних, привредних и ширих друштвених садржаја који сведоче о патриотској привржености нацији и на тзв. малим темама из свакидашњице граде принцип националне доследности. Општеприхватљив назив за овај модалитет постојања националне идеје је "банални национализам". Ближе види: Мајкл Билиг, Банални национализам, Београд 2009.

${ }^{45}$ Наш националнизам, Слога, бр. 42, 17 (30) октобар 1910.

${ }^{46}$ Исидора Секулић, Културни национализам, Нови Србин, јануар-јуни 1913, Сомбор.
} 
је Бог!“47 Морални афекат у коме се национална идеја, у том тренутку кретала, по мишљењу ових мислећих људи, био је пут којим се, у име народних интереса, заправо ишло у однарођавање јер је виртуална представа о сопственим вредностима без имало смисла за комплескну реалност, била опијат који национални интерес уподобљава страначком а овај је, на тај начин фрустрираним припадницима српске нације, нудио садржаје декларисане као опште добро, а заправо су то били конкретни материјални интереси појединаца макијавелистичке склоности. Баш у име превазилажења такве политичке стечене навике, из обриса теоретисања, промаљала се идеја о формирању модерне либералне и демократске странке.

\section{Покушај конституисања Српске демократске странке}

Представљени „интелектуални размах,“ дакле подстакао је и политички покушај коституисања странке која ће све наведене новине у националном изразу унети у страначки програмски оквир. „Наши су се стари мачем у руци борили, пролевали су крв своју за слободу и опстанак Српства. Данас су времена друкчија. Место мача законом у руци, место крви правдом, вечитом, необоривом, светом правдом ваља нам одбијати сваки неправедни нападај на народносни нам живот.“48 Те 1908. године на заједничком послу оснивања српске демократске странке нашли су се заједно представници новог таласа грађанске мисли чији су националне идеје и организационе способности у области културе већ биле препознате, али међу којима је било и знатан број неуподобљених политичких ставова. ${ }^{50}$ Програм станке исписивали су: Тихомир Остојић, Јоца Богданов, Душан Бошковић, Милутин Јакшић и Јован Јоца Лалошевић.

\footnotetext{
47 Лаза Костић, О Змају, Матица српска, Нови Сад 1989, 120-121.

${ }^{48}$ Јован Јоца Лалошевић, Српска демократска странка, Слога, бр. 26, 29. јун (12. јул) 1908.

${ }^{49}$ Конференција која је предложила оснивање странке одржана је 8. јула 1908. године у Турском Бечеју. Конференцији су присуствовали "из Т-Бечеја: Др. Богдан Давидовић адв., Др. Јован Пивнички адв., Партеније Сивчев свешт., Миша Ранковић књиговођа, Светолик Радивојевић трговац. Из Врањева: Младен Боберић свешт., Милош Влашкалин свешт. Из В. Кикинде: Др. Сава Путник адв., Миловој Радовић свешт., Марко Богдан трговац., Др. Арсен Видак лекар., Др. Васа Јакшић адв., Стојан Јакшић ђакон, др. Жарко Јакшић адв. Кандидат. Из Вел. Бечкерека: Жарко Стакић свешт. Из В.С. Миклуша: Петар Агрима свешт. Из Итебеја: Младен Пилић инжинер. Из карлова: Милош Пејић свешт. Из Кумана: Стеван Мирковић свешт. Из Куле: Милан Боберић свешт. Из Мола Ђура Коњовић свешт. Из Новог Сада: Др. Тихомир Остојић проф. Из Панчева: Др. Коста Алексић лекар, др. Влада Алексић лекар, Др. Јоца Богданов сенатор, Др. Душан Бошковић адв. Из Сараволе: Милош Челекетић свешт. Из Сомбора: Др. Јоца Лалошевић адв. Др. Коста Бугарски адв. Из Српске Црње: Милутин Јакшић професор, Милета Јакшић свешт. Из Тараша: Обрад Брусни свешт."; Слога, бр. 26, 29. јун (12. јул) 1908.

50 "Од алмажана и амфибијства Лалошевића преко Милутина Јакшића - до Милете Јакшића, Вељка Петровића и Васе Стајића било је међу демократама заступљено неколико разних нијанса демократизма, те су се они тако тешко прибијали до јединствених гледишта и заједничког програма. Сматрамо да је њихова социјална структура и неповезаност са одговарајућом масовном базом - главни разлог ьховог лутања, а не њихова 'нереалност" и њихов 'утопизам, како су то тврдили либерали. Мада не негирамо ни ову њихову 'нереалност', ипак је сматрамо последицом, а не узроком"; Арпад Лебл, н. д, 113.
} 
Основна слабост ове иницијативе била је одсуство представника аграрног српског становништва ${ }^{51}$ на оснивачкој скупштини. Тај озбиљни проблем није ни касније разрешен и условио је својевсрстан „политички градски елитизам“ који је најчешће спочитаван, од критичара, као непремостиви недостатак. Намера странке била је да, прихватајући легислативну реалност Угарске, политички брани српске националне интересе кроз залагање за основе либералне идеје оног времена: опште право гласа, право на образовање, покретање женског питања, политичку препознатљивост иступа мањинских народа, институционализацију мањинских интереса, отварање тзв. „женског питања“ и друго.

Свесни организационих тешкоћа, покретачи страначког генерисања и водећи креатори програма странке сматрали су да је карактер странке требало употпунити и уподобити са програмом и радом Српске народне самосталне странке, о чему је децидно и писало у програму Српске демократске странке. „Српска демократска странка усваја општа начела автономног програма Српске Народне Самосталне Странке и прима тај програм за основу рада у сврху коначног уређења српске народне црквене аутономије.“52 Странка се у програмском нацрту залагала за одбрану демократских начела слободе говора, штампе, збора и удруживања, затим за економску и политичку слободу без обзира на вероисповест и народну припадност, а као своју „најглавнију дужност“ сматрала је „да друштвеним путем свим силама поради на моралном, културном и привременом препорођају народа. “53

Странка је намеравала да свој рад усредсреди на критику политичких потеза Радикалне странке и да придобије српско становништво за свој програм. „Покрет за оснивањем нове политичке странке међу нама, овостраним Србима у Угарској...се може сматрати и реакцијом против скроз и скроз неродољубиве и јалове политке данашњих српских радикала... Прошло је време заваравању и завођењу народном. Демагошким звучним фразама данас се више не може војевати ни борити.“ ${ }^{54}$ Радикална странка је одговорила својим противкритикама називајући новоформирану странку „мађаронском, несрпском и народносним тежњама противном.“ „И тако се почела стварати у Кикинди нова страка. Не знам како ће се звати али ће то бити језуитска странка...И ено изнели су програм. Све што раде хоће у споразуму са Мађарима.“ 55

Осим радикала, намеру оснивања нове странке критиковала је и Српска народна слободоумна страка, а преко свог гласила Браника и чланка Михајла Полит-Десанчића. „Каква појма има та српска демократска странка о народносном питању, доказује већ и то, кад каже: као демократе моћи ћемо употребити српски језик. Јесте! Ако Вам то држава допусти, а да Вам то држава може допустити,

\footnotetext{
51 Од тридесет двоје присутник: осам су били адвокати, четрнаест свештена лица, затим лекари, професори, трговци, књиговођа и сенатор. Види ближе Саша Марковић, Политичка биографија Јована Јоие Лалошевића, Сомбор, 2011.

${ }^{52}$ Нацрт за програм Српске Демократске странке, Слога, бр. 26, 29. јун (12. јул) 1908.

${ }^{53}$ Наирт за програм Српске Демократске странке, Слога, бр. 26, 29. јун (12. јул) 1908.

${ }^{54}$ Српска Демократска Станка, Слога, бр.27, 6 (19) јул 1908.

${ }^{55}$ Језуитска странка, Застава, бр. 139, 27. јун 1908.
} 
морала би држава имати народносну основу. А зар је збиља народносно питање само језичко питање? Оно је државно-административно. Оно се мора манифестовати у учешћу појединих народа у државном животу посредством администрације... Ми признајемо игемонију мађарског народа, али не признајемо доминацију и супремацију....“56 „Српске демократе ако то чине, стављају се у противност са свима немађарским народностима у Угарској.“57

Михајло Полит-Десанчић је сматрао програм Демократске странке уопштеним и демагошким, а залагање за демократију наративно и теоретски постављено без имало смисла за политичку реалност, атмосферу и начин дневнополитичке борбе у ондашњој Угарској. ${ }^{58}$ По њему је нацрт програма Демократске странке „магловито схватање демократије без конкретне апликације на одношаје српског народа.“59 Отуд је и Полит сматрао да је оснивање ове странке било непотребно и сувишно јер принципи за које се она залагала су постојали у програму, али и искуству деловања Самосталне странке. Тиме се страначки живот Срба у Угарској усложњавао, а у становништву се додатно компликовала ионако дневнополитичком борбом и међусобним оптужбама оптерећена моћ политичког расуђивања. „Ми Срби јесмо демократски народ и на основу демократије ми и желимо осигурање нашега народнога бића. Већ бечкеречки програм у својој 4. тачци узима демократију као основ за преустројство нашега политичкога положаја. Зато у нас Срба није ни потребно стварање какове посебне демократске странке. Српска странка, која хоће да одржи и да осигура народно биће српскога народа, мора бити демократска странка.“60

Позивање на примодијалност сопствене странке и са тим у вези личне политичке биографије, онемогућио је нестанак неповерења и додатно је подстакао страначку и личну анимозност. Потрага за модерном српском политичком парадигмом, без обзира што је била декларативна, никада није доведена до разине успеха. Вишеструки су разлози томе. Најпре званична Угарска државна политика, иритирана успесима Краљевине Србије и одлучна у обрачуну са мањинским национализмима, не само да није пристајала на либерализацију свог мултиетничког друштва, већ је гасила и постојећа права, конкретно код Срба укидајући и црквеношколску аутономију. У тим својим потезима, власт је имала подршку и дела српске интелигенције спреме на политички комформизам. Са друге стране какофонија српског странчарења и политиканства ${ }^{61}$, као оквир у којем су се неке нове идеје и

\footnotetext{
${ }^{56}$ Михајло Полит-Десанчић, Како сам свој век провео, Успомене, Нови Сад 2006, 193.

${ }^{57}$ Михајло Полит-Десанчић, Демократија без народне основе, Браник, бр. 140, 24. јун (7. јул) 1908

58 "По прочитању овог нацрта може се видети, да у том програму није погођен стил политичких програма, јер је помешана многа мотивација и много умствовање, што не може сачињавати садржину једног програма , који мора бити прецизан и задржавати извесне диспозиције", Нацрт за програм српске демократске странке, Браник, бр. 146, 2 (15) јул 1908.

${ }^{59}$ Михајло Полит-Десанчић, Демократија без народносне основе, Браник, бр. 140, 24. јун (7. јул) 1908.

${ }^{60}$ Михајло Полит-Дечанчић, Беседе, III део, прва књига, Нови Сад, 1910, Наш положај, 275.

${ }^{61}$ Таквав карактер политичког рада Јован Цвијић је окарактерисао као "политичку циганију", чија је основа "непрекидна свађа" а "у целом њиховом раду преовлађују лични мотиви, кашто простачка таштина, мотре један на другог и често су у стању изнети један о другоме и најневероватније инфамије. Даље има много пакости, злобе, мржње"; Јован Цвијић, О националном раду, Београд 1907, 13.
} 
садржаји могли запатити, чврсто се држећи својих позиција, није дозвољавала нове страначке иступе и саму идеју, због угрожених сопствених привилегија и интересних достигнућа, је дочекала „на нож.“ Иако су се сви позивали на демократизацију и модернизацију политичког артикулисања, најочигледније је да ни једног ни другог није било. Инсистирање на чисто концептуалном присуству одсуства не доводи до присутности одсутног, већ до убрзаног губљена и оног што је већ присутно. Неприлагодљив и ех катедра страначки програм имао је и другу битну мањкавост која није омогућила стварање странке, то је недостатак елемента организације. $^{62}$ И поред свих покушаја странка није успела да организује своју мрежу одбора по местима у Војводини, а тиме и омасови своје присуство и повећа број присталица.

Политичка дистинкција и опортунизам, на овај начин остарени условили су неуспех страначког артикулисања идеја које су осмислиле „демократски национализам“ код Срба. Био је то, по нашем суду, двоструки пораз. Један од стране мађарског искључивог национализма, други од предострожности политичких представника српског национализма, који нису намеравали да романтичарски „етнонационализма“ ослоњен на територијално размахивање, надоместе „национализмом“ спремним за културно размахивање као предусловом за територијално проширење. Идеја о стварању демократске странке остала је да флуктуира између идеологије хуманизма, страначке неорганизованости, општости демократских програмских начела, политикантске неуклопљивости културнопросветне доследности многих и комформистичке острашћености појединаца. Стварање југословенске државе, након Првог светског рата, и интегрисање Војводине у њен састав преко Краљевине Србије, улило је нову наду у „демократски национализам.“ Ипак даље се од национално-етничке сегрегације није отишло, изазов остварења комплементарног националног идентитета чији је садржај вишеслојан и надетнички, био је за многобројне исувишан и непотребан, а за малобројне незаобилазан, окарактерисан и могућ. За једне и друге, што је највећа слабост, становиште о идентитету било је условљено политикантством и тиме, иако су сви желели, није остварен дисконтинуитет са нерешеним националним питањем из претходних времена. ${ }^{63}$

\footnotetext{
62 "Да би једна политичка партија могла постојати њој су потребна два битна елемента: 1. организација и 2. програм.";Љубомир. Тадић, Наука о политици..., 313.

${ }^{63}$ Ближе види: Саша Марковић, Национално и уставно питање у делатности странака у Војводини, докторска дисертација, Нови Сад, 2008.
} 
Извори и литература:

Извор:

Рукописно одељење Матице српске (РОМС).

Литература:

Билиг, Мајкл, Банални национализам, Београд 2009.

Екмеџић, Милорад, Стварање Југославије, 1790 - 1918, књига 2, Просвета, Београд 1989.

Гелнер, Ернест, Наиије и национализам, Нови Сад 1997.

Gellner, Ernest, Nationalism, London 1997.

Готфрид, Хердер, Јохан, Расправа о пореклу језика, Сремски Карловци 1989.

Кириловић, Димитрије, Помађаривање у бившој Угарској, Нови Сад 1935.

Kohn, Hans, Nationalism:Its Meaning and History, Princeton, Van Nostrand 1955.

Костић, Лаза, O Змају, Матица српска, Нови Сад 1989.

Конференција у Матици српској о 'књигама за народ', Остојић, Тихомир (1902), Извештај референта Редакиијског одбора, Нови Сад.

Лебл, Арпад, Грађанске партије у Војводини 1887-1918, Филозофски факултет у Новом Саду, Институт за историју, Нови Сад 1979.

Лебл, Арпад, Политички лик Васе Стајића, изабрани политички и идеолошки списи, Прогрес, Нови Сад 1963.

Матица српска 1826-1926, Типографија, Загреб 1926.

Марковић, Саша, Начионално и уставно питање у делатности странака у Војводини 1929 1941, докторска дисертација, Нови Сад 2008.

Марковић, Саша, Политичка биографија Јована Јоче Лалочевића, Сомбор 2011.

Марковић, Саша, Сомборски лист Нови Србин у трагању за културним обрасием у националној идеји, Зборник радова Античка култура, европско и српско наслеђе, Друштво за Античке студије Србије, Институт за теолошка истраживања, Београд 2010.

Марковић, Саша, Бесермењи, Снежана, 'Културни национализам' у политичкој мисли код Срба почетком 20. века, Српска политичка мисао, број 4, Београд 2011, 377 - 394.

Микавица, Дејан, Михајло Полит.Десанчић, Филозофски факултет, Нови Сад 2007.

Микавица, Дејан, Лаза Костић, политичка биографија, Нови Сад 2011.

Микавица, Дејан, Гавриловић, Владан, Васин, Горан, Законски чланак XXVII, Знаменита документа за историју српског народа 1538 - 1918, Нови Сад 2007.

Милисавац, Живан, Историја Матице српске, 1826 - 1924, Нови Сад 1965.

Милисавац, Живан, Историја Матице српске 1880-1918, књига III, Матица српска, Нови Сад 2000.

Остојић, Тихомир, Програм књига за народ, Летопис Матице српске, књига 294, свеска 4, 1913.

Пал, Тибор, Мађарско политичко јавно мъење и српско питање на Балкану 1903-1914 , докторска дисертација, Филозофски факултет, Нови Сад 2009.

Писмо Тихомира Остојића, секретара Матице српске и Гедеона Дунђерског, председника Матице српске Славној српској православној ирквеној опћини Мелениии од 11 / 22.

Октобра 1912. године; Матица српска ДК 844, Ин. Бр. 6932.

Полит-Дечанчић, Михајло, Беседе, III део, прва књига, Нови Сад 1910.

Полит-Десанчић, Михајло (2006), Како сам свој век провео, Успомене, Нови Сад 2006.

Петровић, Вељко, Времена и догађаји, Матица српска, Нови Сад 1954. 
Plamenatz, John, Two types of Nationalism, in Nationalism. The Nature and Evolutio of an Idea, E. Kamenka, London, 1973, pp. 24-36.

Петровић, Никола, Наџионални и сочијални покрети и њихови носиоци 1914-1918. у Војводини, Зборник радова Стварање југословенске државе 1918, Институт за савремену историју, Народна књига, Београд 1983.

Пламенац, Јован, Два типа национализма, Изабрани списи, Фондација John Plamenatz, Бар 2001.

Раденић, Андрија, Борба за политичка права у Јужној Угарској, Историја српског народа, Српска књижевна задруга, Београд, књига VI-1, 1994.

Ракић, Лазар, Радикална странка у Војводини 1902-1919, Филозофски факултет, Нови Сад 1971.

Ракић, Лазар, Јама Томић, (1856-1922.), Нови Сад 1986.

Ракић, Лазар, Грађанске политичке странке у Војводини до Првог светског рата, Годишњак друштва историчара САП Војводине, 1976, 97-105

Ренан, Ернест, Шта је наиија ?, Београд 1907.

Ренан, Ернест, Шта је народ ?, Београд 1883.

Ситон-Ватсон, Хjy (Hugh Seton-Watson), Нације и државе, Глобус, Загреб 1977.

Суботић, Милан, На други поглед, Прилог студијама национализма, Београд 2007.

Стајић, Васа, Песништво и родољубље, Летопис Матице српске, св. 288, 1912.

Секулић, Исидора, Културни начионализам, Нови Србин, јануар-јуни 1913, Сомбор.

Тадић, Љубомир, Наука о политици, Рад, Београд 1988.

Тодорова, Марија, Имагинарни Балкан, Београд 2006.

Цвијић, Јован, О начионалном раду, Београд 1907.

Чубриловић, Васа, Историја политичке мисли у Србији 19. века, Просвета, Београд 1958.

Чулиновић, Фердо, Држсвноправна хисторија југословенских земаља 19. и 20. вијека, књига 1, Школска књига, Загреб 1956.

Хајзинха, Јохан, Национализам и патриотизам у Европи на крају XIX века, Прометеј, Нови Сад 1996.

\section{Штампа:}

Слога, Сомбор.

Браник, Нови Сад.

Застава, Нови Сад.

Нови Србин, Сомбор.

Летопис Матице српске, Нови Сад. 


\title{
POLITICKING OR PROLEGOMENON OF THE DEMOCRATIC PARTY IN VOJVODINA SERBS OF THE AUSTRO-HUNGARIAN MONARCHY
}

\begin{abstract}
Summary
The political position of Serbs from Vojvodina in the Austro-Hungarian Monarchy in the early twentieth century was very complex. Although the AustroHungarian Empire tried to present its social situation as well as a progress in democratization, the reality was quite different. The demographic structure of the population of Hungary imperatively conditioned the democratization of the society for its survival, but the state policy tended to Hungarian national exclusiveness. In such a political radicalization of attitudes, the political and party articulation of Serbs was a very uncertain mission. Even the political representatives of the Serbian nation in Vojvodina themselves were burdened by the party antagonism and the interest politicking. Any ideas or political actions were viewed through the prism of their own success or failure. Hence the labeling became normal, and any more liberal attempt remained in the shadow of charges for opportunism. Degradation and mutual denunciation additionally weakened the identity of the Serb political elite. The consequence was their helpless watching the abolition of church and school autonomy of Serbs in the Monarchy. An unsuccessful attempt to form the Serbian Democratic Party in Hungary was a result of the defeated massification ideas of liberal-democratic ideas, their program articulation and party organization. Condemnation of existing Serbian parties was also an intractable problem in the constitution of the party.
\end{abstract}

Keywords: Serbs, politics, national identity, party, Hungary. 